\title{
Predation of Desmodus rotundus Geoffroy, 1810 (Phyllostomidae, Chiroptera) by Epicrates cenchria (Linnaeus, I758) (Boidae, Reptilia) in an Ecuadorian Cave
}

\author{
Sarah Martin-Solano', Theofilos Toulkeridis 2,3 , \\ Aaron Addison ${ }^{4}$, Wilmer E. Pozo-Rivera ${ }^{5}$
}

I Carrera de Biotecnologia, Departamento Ciencias de la Vida y de la Agricultura, Universidad de las Fuerzas Armadas ESPE, Sangolqui, Av. General Rumiñahui s/n, Ecuador 2 Departamento de Seguridad y Defensa, Universidad de las Fuerzas Armadas ESPE, Av. General Rumiñahui s/n, Sangolqui, Ecuador 3 Centro Panamericano de Estudios e Investigaciones Geográficas (CEPEIGE), Quito, Ecuador 4 Washington University in St. Louis, St. Louis, MO, USA 5 Laboratorio de Zoología y Museo de Investigaciones Zoológicas IASA (MIZI), Carrera de Ciencias Agropecuarias, Departamento Ciencias de la Vida y de la Agricultura, Universidad de las Fuerzas Armadas ESPE, Av. General Rumiñahui s/n P.O.Box 171-5-231-B, Sangolqui, Ecuador

Corresponding author: Theofilos Toulkeridis (ttoulkeridis@espe.edu.ec)

Academic editor: O.Moldovan | Received 5 April 2016 | Accepted 19 July 2016 | Published 20 September 2016

http://zoobank.org/AB6009FB-C23F-410E-9C93-FC2581AE2848

Citation: Martin-Solano S, Toulkeridis T, Addison A, Pozo-Rivera WE (2016) Predation of Desmodus rotundus Geoffroy, 1810 (Phyllostomidae, Chiroptera) by Epicrates cenchria (Linnaeus, 1758) (Boidae, Reptilia) in an Ecuadorian Cave. Subterranean Biology 19: 41-50. doi: 10.3897/subtbiol.19.8731

\begin{abstract}
Bats are mammals of the Order Chiroptera. They are highly adaptable to several habitats and their ecology makes them vulnerable to predators. Bats are a common prey of snakes, but description of this kind of predation are rare. This study describes the event of predation of an Epicrates cenchria on a Desmodus rotundus, in a cave in Tena, Ecuador. Records of Desmodus rotundus are known from caves just as Epicrates cenchria. Castillo Cave has a total mapped length of 450 meters. The phase of constriction lasted for 10 $\min 2 \mathrm{~s}$, a duration superior than other studies, due to the size of Desmodus rotundus. The terrestrial locomotion behavior of $D$. rotundus, makes it an easy target for $E$. cenchria. The predation event occurred on the floor, a rare case, which has not been described in other events of predation in caves. The cave is located in a disturbed habitat, because it is irrigated by wastewaters. But both species seems to be adapted to the environment. This study confirms that predation of bats in caves by snakes does occur.
\end{abstract}

Copyright Sarah Martin-Solano et al. This is an open access article distributed under the terms of the Creative Commons Attribution License (CC BY 4.0), which permits unrestricted use, distribution, and reproduction in any medium, provided the original author and source are credited. 


\section{Keywords}

Bat predation, boids, behavior, attack

\section{Introduction}

Bats are mammals of the Order Chiroptera. They are highly adaptable to several habitats: trees (Jachowski et al. 2016), under plantain leaves (Rodríguez-Herrera et al. 2011), caves (Zortea et al. 2015), human settlements (Whitaker et al. 2006, Streicker et al. 2013), etc. Like most animals, they are not predator free. There is a list of enemies mentioned in the literature: monkeys, loris, mustelids (weasels), minks (Goodpaster and Hoffmeister 1950), raccoons, opossums, cats and even bats themselves. Mikula (2015) recently published a literature review of different fishes (such as salmons, catfishes and sharks) that prey on bats; and amphibians such as Bufonidae, Hylidae and Leptodactylidae, prey on bats too. Giant centipedes were also observed killing bats in a cave in Venezuela (Molinari et al. 2005). Spiders have been recently suggested that their predation on bats is not that uncommon (Nyffeler and Knörnschild 2013). But the most common predators are birds and snakes (Hill and Smith 1984, Mickleburgh et al. 1992). Within birds we can mention raptors such as Accipiter tachiro, Aquila walhbergi, Falco subbuteo, hawks (Lee and Kuo 2001) and owls (Julian and Altringham 1994) such as Asio stygius (Motta Junior and Taddei 1992), and Tyto alba (Vargas et al. 2002), but there are events of other types of birds such as Momotus momota preying on a bat (Chacón-Madrigal and Barrantes 2004). Within snakes we can mention the case reported by Hammer and Arlettaz (1998), another in western Iran by a Colubridae (Sharifi et al. 2014). Esbérard and Vrcibradic (2007) made a review of recorded cases for the neotropical region, but we can also name a more recently case of Hemorrhois hippocrepis preying on Plecotus austriacus and on Eptesicus serotinus (Schreber, 1774) I Eptesicus isabellinus (Temminck, 1839) (Garrido-García et al. 2013). Two observations were reported in caves in Mexico where snakes caught bats hanging off the roof (BBC 2014, BBC Earth 2014).

Desmodus rotundus (common vampire) is one of three sanguivorous bat species (Simmons 2005, Kwon and Gardner 2007), that habits mainly in caves but also can be found in tree holes (Pozo and Cueva pers. comm.). Normally they attack their prey flying stealthy and perching on the dorsal face of large mammals like cows, tapirs, deer and peccaries (personal observations). D. rotundus is distributed from North of Tamaulipas and Sonora (México) to Uruguay, northern Argentina and central Chile (Greenhall et al. 1983). In Caribbean Islands is found only in Trinidad (Mancina, pers. com.) and Margarita Islands (Wilson and Reeder 2005). Ecuadorian subspecies belong to Desmodus rotundus rotundus (Greenhall et al. 1983) which it has been recording in all geographic altitudes zones (Albuja-V et al. 2012). Desmodus in the day rests perching on the roof of the caves, but occasionally are found walking on the floor when they are accidentally dropped from roof (Wilmer E. Pozo-Rivera Observations). Over the floor Desmodus recently awake, walk helping with their legs and elbows. 
Epicrates seems to be a major threat to bats on the neotropics. Half of the records published on the review made by Esbérard and Vrcibradic (2007) involving boid snakes species were Epicrates sp. Epicrates cenchria is endemic to Central and South America (McDiarmid et al. 1999). Ecuador has the subspecies Epicrates cenchria gaigei (Uetz and Hallermann 2016). It is described as a medium sized (Duellman 1978, Ross and Marzec 1990) terrestrial nocturnal snake (Savage 2002). Characterized by having a blue iridescence in sunlight, this viviparous snake was found in primary and secondary forest, on the ground and on the trees (Duellman 1978). But is also very common to find this species close to rivers where food is abundant (Gonzálves 2006). Birds, rodents, and bats (Lemke 1978, Medeiros de Pinho et al. 2009, Pizzatto et al. 2009) are common preys of Epicrates cenchria.

We report the first record of predation of Desmodus rotundus (Common Vampire Bat) by Epicrates cenchria (Rainbow Boa) in a cave in Ecuador.

\section{Methods}

The predation event was observed in the late afternoon of the $5^{\text {th }}$ of December 2015 during 25 minutes and mostly filmed during the regular cave monitoring of the Castillo Cave, near the city of Tena, in Napo province (Fig 1).

\section{Geological setting of Castillo Cave}

The area around the city of Tena is predominantly covered with deposits $(200-700 \mathrm{~m})$ of the Napo Formation, which consists of cyclic sequences of limestones, shales, and sandstones deposited on a low-energy shallow marine platform between the Albian and the Campanian (Estupiñan et al. 2010).

The Napo karst may be considered a shallow one, with direct infiltration of surface streams along lithological contacts such as those between limestones and shales or between different types of limestones. Due to the thinness of the lithological units and their alteration, often "superposed underground streams" are encountered that use different lithological contacts among the same formation. The Castillo Cave has total mapped length of $450 \mathrm{~m}$ and three exits-entrances, being a western, a central and an eastern end. The meandering form of the cave is truncated by a river, which flows from north to south. The maximum height in one of the open chambers along the corridors is of approximately three meters. In such chambers rests the highest populations of bats (unidentified species).

One of the entrances of the Castillo Cave is only $60 \mathrm{~m}$ in distance of a major paved road in the outside area of Tena city, but the surface karst morphology of the cave is hidden by the dense jungle forest, having the corresponding diverse flora and wildlife. The inner cave fauna include a typical cave fauna: mammals (chiroptera), reptiles, amphibians, arthropods, actinopterygii (Peck 1985, Peck 1994, Romero and Paulson 2001, Hoese G et al. 2015, Toulkeridis et al. 2015). 


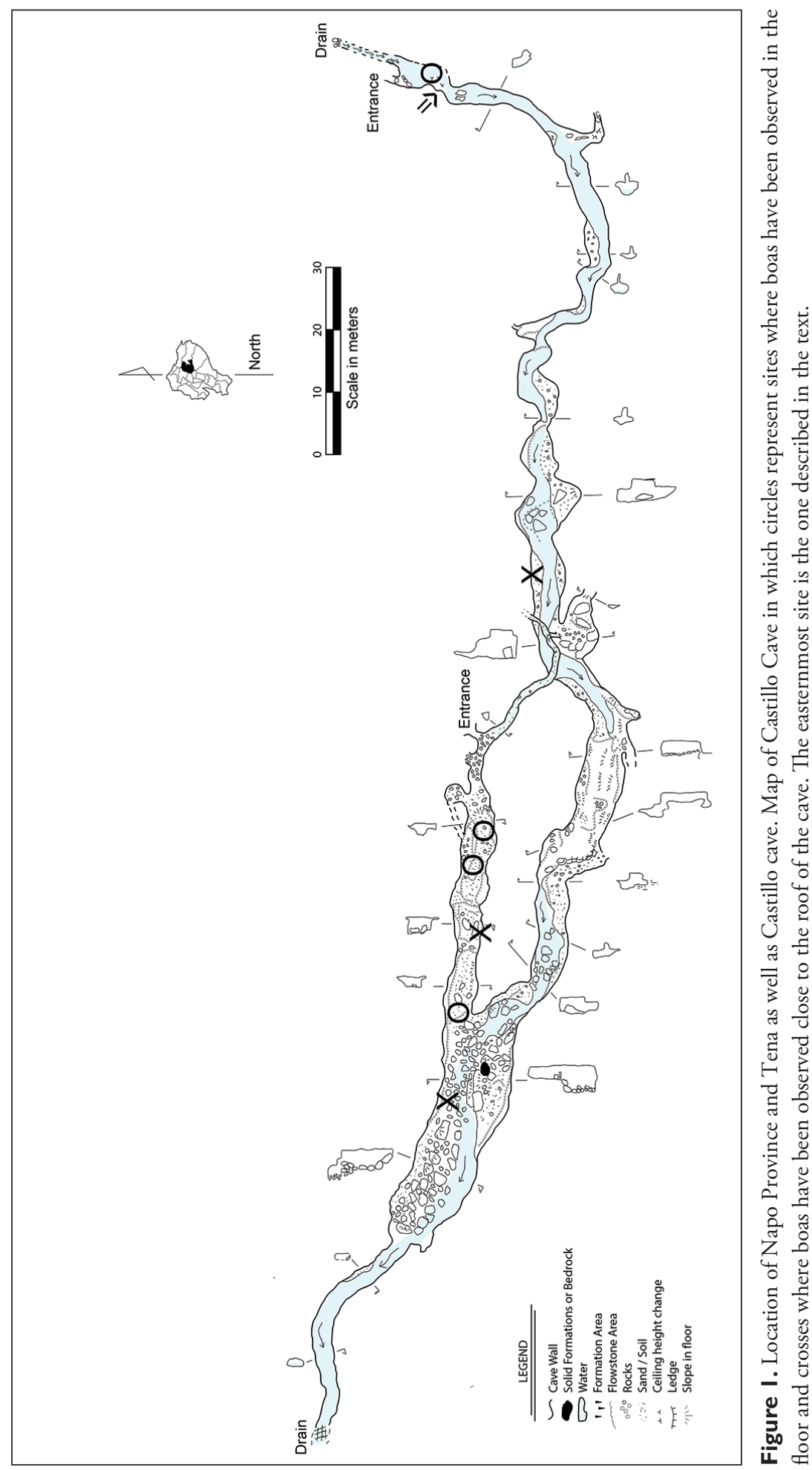




\section{Results}

\section{Observation}

In the late afternoon of the $5^{\text {th }}$ of December 2015 as part of the regular cave monitoring we entered the Castillo Cave, outside the city of Tena, where we met a first rainbow boa, Epicrates cenchria, some 25 meters inside the side entrance. At 4:50 p.m. local time, we observed the catch and recorded most of the predation behavior of a second rainbow boa the Epicrates cenchria on a Desmodus rotundus adult female in the Castillo Cave close to the northern exit of the cave. The whole event, from the catch until the end of the meal, took approximately 25 minutes. The recorded part in high resolution corresponds to the final act and is as long as some 16 minutes and is summarized and edited in https://www.youtube.com/watch? $=$ =amtdKGsT7fU.

The event occurred as follows: A $-140 \mathrm{~cm}$ long E. cenchria was waiting with its open mouth around a final corner in the eastern exit of the Castillo cave (Fig. 1) for a prey, having just a fourth of its body some $30-35 \mathrm{~cm}$ above ground. A D. rotundus flying into the cave in a correspondent low height was caught upfront with its head in E. cenchria's mouth. Almost immediately E. cenchria brought $D$. rotundus down to the cave floor, where the body of D. rotundus got encircled, having E. cenchria's head up, and way above the prey. Resistance of $D$. rotundus ended some two minutes after the catch. Nonetheless, E. cenchria remained in that position for some seven more minutes moving just slowly with the whole body (Fig. 2A). Once being assured, that D. rotundus had no more life signals, E. cenchria left the dead body on the ground (Fig. 2B) and started to open its jaws in the air for some two more minutes, turning around the head some three times. Then E. cenchria tried some five times to bite in different parts of the body to see which part would fit in the mouth best (Fig 2C). Every try and exploration took between 30 to 60 seconds. Finally, E. cenchria decided to introduce the head of $D$. rotundus first into the mouth and proceeds to bite with intent to swallow D. rotundus by some 11 minutes. During these 11 minutes, E. cenchria took out the prey of its mouth the fifth time, while at the sixth time, it lift $D$. rotundus slightly off the ground and turned around the body's prey until supine position revealing clearly its age-sex class (Fig. 2D), which belongs to a non-pregnant adult female. There is no evidence of functional mammary gland that warn us that the prey didn't have a suckling infant. This phase lasted for 2 minutes and 17 seconds. Once the prey was covered, E. cenchria try swallowing Desmodus body by mandibular detachment and using retractable light movements of its teeth, this intention lasted for 2 minutes and 35 seconds.

Viewing that the prey was too difficult to swallow because of the joint stiffness shoulder, E. cenchria begins again the process of constriction (Fig. 2E), for which moves their initial proportion of their body and wraps hardly the prey, this process extend by 1 minute and 2 seconds and immediately begins definitive swallow process until swallowing the whole Desmodus with a duration of 4 minutes and 50 seconds (Fig. 2F). The last part to be swallowed has been feet and wings. E. cenchria remained in that area for some half an hour, swallowing the bat further inside the body, before it moved away (Fig. 2G, H). 

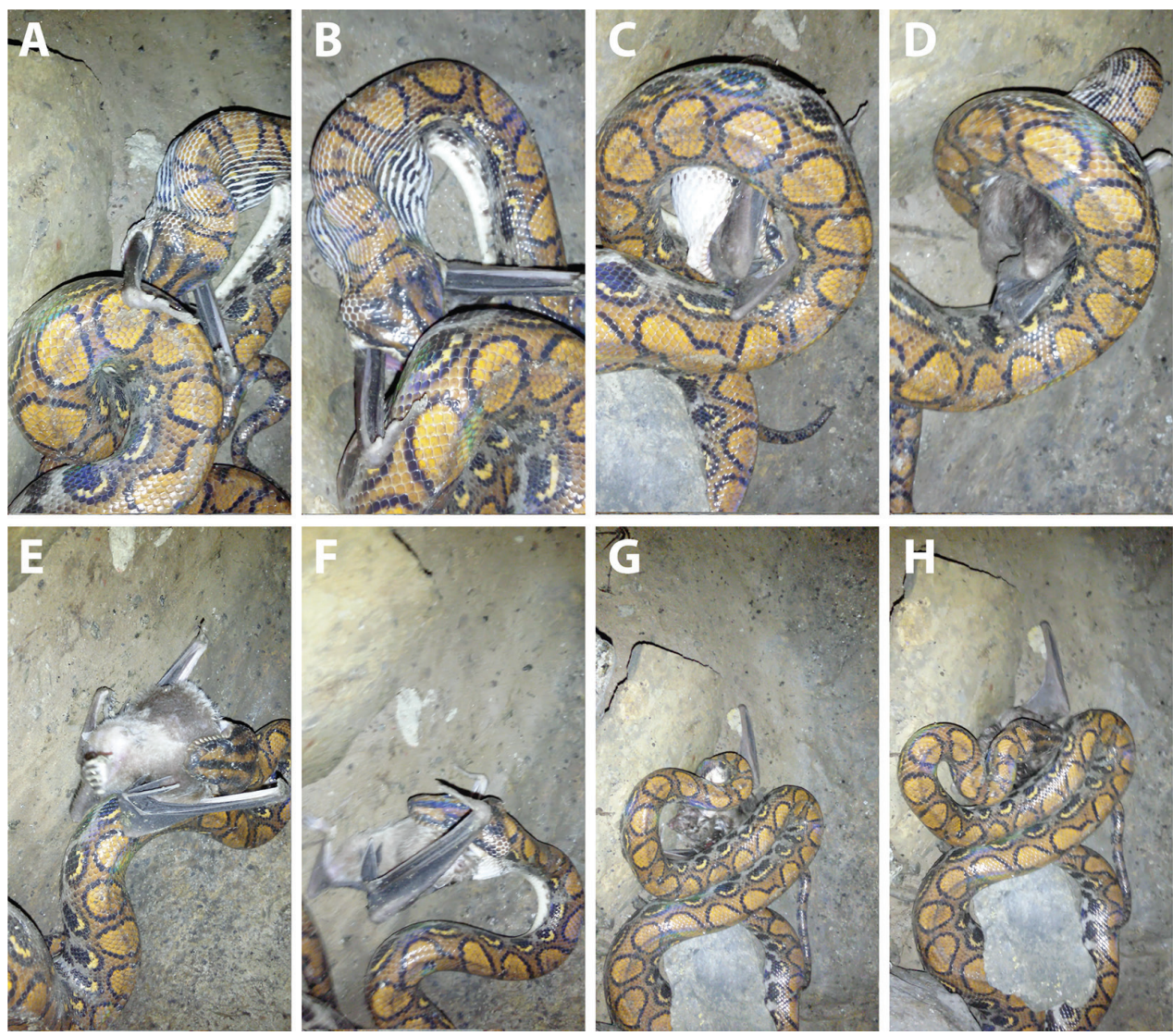

Figure 2. A Rainbow Boa (Epicrates cenchria) maintains the prey in the mouth with the interest to make sure it is dead, elongated thumb with three typical bearings evidences the species of the Common Vampire Bat (Desmodus rotundus) B E. cenchria releases the dead prey C E. cenchria turns around D. rotundus having the first attempt to swallow prey $\mathbf{D}$ Evidence of sex-age category of the prey, being a female adult; 2e: Starting the second constriction $\mathbf{F}$ After the second constriction $E$. cenchria swallows almost entirely $D$. rotundus $\mathbf{G}, \mathbf{H}$ Prey is almost completely eaten except for the wings, but the three typical bearings can be seen on the thumb of $D$. rotundus.

\section{Discussion}

Predation of bats by snakes, is not that infrequent (Davis 1951, Steyn 1964, Mankins and Meyer 1965, Thomas 1974, Schatti 1984, Lewis et al. 2009). It is well registered in general websites but few are well documented and published. However reports of $E$. cenchria predating on bats are rare in caves the first record was documented by Lemke (1978), in a cave in Colombia and the second record was registered by Ramos Donato et al. (2012) in a cave in Brazil.

Concerning the prey, they are all, medium sized bats (Greenhall et al. 1983, Lassieur and Wilson 1989, Cloutier and Thomas 1992, Kwon and Gardner 2007). 
In Colombia, the bat species was Carollia perspicillata, and in Brazil Lonchorhina aurita. However, our record is the first to observe the heaviest and largest bat such as Desmodus rotundus. In Colombia, there was only one species of bat in the cave, however in Brazil's study they registered also Desmodus rotundus, which can implied that Desmodus rotundus might belong to their diet too. It is important to notice that Desmodus rotundus has a terrestrial locomotion (Riskin et al. 2006) that E. cenchria can take advantage because E. cenchria was observed several times on the ground ( $\mathrm{T}$. T. observations).

The other two studies have not described the process of the event in detail. The predation took place in the three studies during the day but at different moments. In our study, the observation was at 4:50 p.m. For a nocturnal snake and for D. rotundus, is almost dusk. And D. rotundus can start their foraging activity at different times each day (Wimsatt 1969), and the roost exist can be influenced by human activity or weather. If it is cloudy, the weather during observation, the foraging activity of both individuals can start earlier. The constriction lasted for 4 minutes in Brazil, while in our study it lasted for 10 minutes and 2 seconds. This can be due to the size of $D$. rotundus. Also, in relation to the environment, the caves are located close to rivers which corresponds to the snakes ecology (Gonzálves 2006). Nevertheless, the water of the Castill cave is contaminated with waste water, establishing that the habitat is disturbed. However it appears that both species, Desmodus rotundus and E. cenchria, are adapted to this environment.

\section{Conclusions}

This is the first report for Ecuador, of Epicrates cenchria predating on a Desmodus rotun$d u s$, in a cave, and the third report for Latin America. With such a few reports, we cannot affirm that this kind of predation is common, but we suggest that a detailed study in this population would help us confirmed that this behavior is more than usual.

\section{Acknowledgements}

We are indebted to the owners of the caves visited that allowed access to their property and caves in and around Tena, and the Family Castillo in Toglo in particular. We are also grateful to the Paulo Clemente and the Municipality of Tena for the permits given. We acknowledge as well the very constructive reviews of an earlier version of this manuscript by Dr. Marco Suarez and an anonymous reviewer of Subterranean Biology and the editorial handling by Dr. Oana Moldovan. This study is also part of the research project of Toulkeridis (2014-PIC-012) of the Universidad de las Fuerzas Armadas ESPE. 


\section{References}

Albuja-V L, Almendariz-C A, Barriga-S R, Montalvo-E L, Cáceres-F F, Román-C J (Eds) (2012) Fauna de Vertebrados del Ecuador (Vol. 12). Arial, Quito, 490 pp.

BBC (2014) Bat-eating snakes - Natural World: The Bat Man of Mexico: Preview. https:// www.youtube.com/watch? $=\mathrm{k} 7 \mathrm{hfhx} 1 \mathrm{PSl} 8$

BBC Earth (2014) Bat-eating Snakes of Mexico! - Deadly 60. https://www.youtube.com/ watch? $=\mathrm{dOwLPR} 2 \mathrm{i} 93 \mathrm{Y}$

Cloutier D, Thomas DW (1992) Carollia perspicillata. Mammalian Species Archive 417: 1-9.

Chacón-Madrigal E, Barrantes G (2004) Blue-crowned Motmot (Momotus momota) predation on a Long-tongued Bat (Glossophaginae). Wilson Bulletin 116(1): 108-110. doi: 10.1676/03-099

Davis WB (1951) Bat, Molossus nigricans, eaten by the rat snake, Elaphe laeta. Journal of Mammalogy 32(2): 219-219. doi: 10.1093/jmammal/32.2.219-a

Duellman WE (1978) The Biology of an Equatorial Herpetofauna in Amazonian Ecuador. University of Kansas, Museum of Natural History, Kansas, 352 pp.

Esbérard CEL, Vrcibradic D (2007) Snakes preying on bats: new records from Brazil and a review of recorded cases in the Neotropical Region. Revista Brasileira de Zoologia 24: 848-853. doi: 10.1590/S0101-81752007000300036

Estupiñan J, Marfil R, Scherer M, Permanyer A (2010) Reservoir sandstones of the Cretaceous Napo Formation $\mathrm{U}$ and $\mathrm{T}$ members in the Oriente Basin, Ecuador: links between diagenesis and sequence stratigraphy. Journal of Petroleum Geology 33(3): 221-246. doi: 10.1111/j.1747-5457.2010.00475.x

Garrido-García JA, Schreur G, Pleguezuelos JM (2013) Occasional bat predation by the horseshoe whip snake (Reptilia, Colubridae). Galemys 25: 59-61. doi: 10.7325/Galemys.2013.N01

Gonzálves E (2006) Introducción a la boa arcoiris Epicrates cenchria. Jangala-Magazine Terrariofilia y Naturaleza 4: 15-26.

Goodpaster W, Hoffmeister DF (1950) Bats as prey for mink in Kentucky cave. Journal of Mammalogy 31(4): 457-457. doi: 10.1093/jmammal/31.4.457

Greenhall AM, Joermann G, Schmidt U (1983) Desmodus rotundus. Mammalian Species Archive 202: 1-6. doi: 10.2307/3503895

Hammer M, Arlettaz R (1998) A case of snake predation upon bats in northern Morocco: some implications for designing bat grilles. Journal of Zoology 245(2): 211-212. doi: 10.1111/j.1469-7998.1998.tb00090.x

Hill J, Smith J (1984) Bats: A Natural History. University of Texas Press, Austin, 243 pp.

Hoese G, Addison A, Toulkeridis T, Toomey RI (2015) Observation of the Catfish Chaetostoma microps Climbing in a Cave in Tena, Ecuador. Subterranean Biology 15: 29-35. doi: 10.3897/subtbiol.15.4809

Jachowski DS, Rota CT, Dobony CA, Ford WM, Edwards JW (2016) Seeing the forest through the trees: considering roost-site selection at multiple spatial scales. PLoS ONE 11(3): e0150011. doi: 10.1371/journal.pone.0150011

Julian S, Altringham JD (1994) Bat predation by a tawny owl. Naturalist 119: 49-56.

Kwon M, Gardner A (2007) Subfamily Desmodontinae JA Wagner, 1840. In: Gardner A (Ed.) Mammals of Southamerica: Volume I Marsupials, Xenarthrans, Shrews, and Bats. The University of Chicago Press, Chicago, 218-224 
Lassieur S, Wilson DE (1989) Lonchorhina aurita. Mammalian Species 347: 1-4. doi: $10.2307 / 3504274$

Lee YF, Kuo YM (2001) Predation on Mexican freetailed bats by Peregrine Falcons and Redtailed Hawks. Journal of Raptor Research 35: 115-123.

Lemke TO (1978) Predation upon bats by Epicrates cenchris cenchris in Colombia. Herpetological review 9: 47.

Lewis TR, Nash DJ, Grant PBC (2009) Predation by Corallus annulatus (Boidae) on Rhynchonycteris naso (Emballonuridae) in a lowland tropical wet forest, Costa Rica. Cuadernos de herpetología 23: 93-96.

Mankins JV, Meyer JR (1965) Rat snake preys on bat in total darkness. Journal of Mammalogy 46(3): 496-496.

McDiarmid R, Campbell J, Touré T (1999) Snakes Species of the World: A Taxonomic and Geographical Reference. Vol. 1. The Herpetologist's League, Washington DC, 511 pp.

Medeiros de Pinho G, Oliveira de Lima D, Nogueira Da Costa P, Dos Santos Fernandez FA (2009) Epichrates cenchria (Brazilian Rainbow Boa) diet. Herpetological Review 40(3): 354-355.

Mickleburgh SP, Hutson AM, Racey PA (Eds) (1992) Old World fruit bats - An action plan for their conservation. IUCN, Gland, 252 pp. doi: 10.2305/IUCN.CH.1992.SSC-AP.6.en

Mikula P (2015) Fish and amphibians as bat predators. European Journal of Ecology 1(1): 71. doi: 10.1515/eje-2015-0010

Molinari J, Gutiérrez EE, De Ascençao AA, Arends A, Márquez RJ (2005) Predation by Giant Centipedes, Scolopendra gigantea, on Three Species of Bats in a Venezuelan Cave. Caribbean Journal of Science 41(2): 340-3446.

Motta Junior JC, Taddei VA (1992) Bats as prey of stygian owls in southeastern Brazil. Journal of Raptor Research 26(4): 259-260.

Nyffeler M, Knörnschild M (2013) Bat predation by spiders. PLoS ONE 8(3): e58120. doi: 10.1371 /journal.pone.0058120

Peck SB (1985) The invertebrate faunas of tropical American caves. Part 6: Jumandi Cave, Ecuador. International Journal of Speleology 14: 1-8. doi: 10.5038/1827-806X.14.1.1

Peck SB (1994) Ecuador. In: Juberthie C, Decu V (Eds) Encyclopaedia Biospeologica. Societé de Biospéologie, Moulis, Bucarest, 551-560

Pizzatto L, Marques OAV, Facure K (2009) Food habits of Brazilian boid snakes: overview and new data, with special reference to Corallus hortulanus. Amphibia - Reptilia 30: 533-544. doi: 10.1163/156853809789647121

Ramos Donato C, Trindade Dantas MA, Da Rocha PA (2012) Epichrates cenchria (Rainbow Boa). Diet and foraging behavior. Herpetological review 43(2): 343-344.

Riskin DK, Parsons S, Schutt WA, Carter GG, Hermanson JW (2006) Terrestrial locomotion of the New Zealand short-tailed bat Mystacina tuberculata and the common vampire bat Desmodus rotundus. Journal of Experimental Biology 209(9): 1725-1736. doi: 10.1242/jeb.02186

Rodríguez-Herrera B, Ceballos G, Medellín RA (2011) Ecological aspects of the tent building process by Ectophylla alba (Chiroptera: Phyllostomidae). Acta Chiropterologica 13(2): 365-372. doi: 10.3161/150811011X624839

Romero A, Paulson KE (2001) Humboldt's alleged subterranean fish from Ecuador. Journal of Spelean History 35(2): 56-59. 
Ross RA, Marzec G (1990) The reproductive husbandry of pythons and boas. Institute for Herpetological Research, Standford, 270 pp.

Savage JM (2002) The Amphibians and Reptiles of Costa Rica: A Herpetofauna between two continents, between two seas. The University of Chicago Press, Chicago, 934 pp.

Schatti B (1984) Fledermause als Nahrung von Schlangen. Bonner Zoologische Betrage 35: $335-342$.

Sharifi M, Akmali V, Fathinia B, Vaissi S, Esmaieli Rineh S (2014) Record of predation on the bat Rhinopoma microphyllum (Chiroptera: Rhinopomatidae) by the Spalerosophis microlepis (Reptilia: Colubridae), in western Iran. Galemys 26: 114-118. doi: 10.7325/Galemys.2014.N6

Simmons N (2005) Order Chiroptera. In: Wilson DE, Reeder DM (Eds) Mammal Species of the World: A Taxonomic and Geographica Reference. The Johns Hopkins University Press, Baltimore, 312-529.

Steyn P (1964) Python eats fruit bat. African Wild Life 18: 258.

Streicker DG, Franka R, Jackson FR, Rupprecht CE (2013) Anthropogenic roost switching and rabies virus dynamics in house-roosting big brown bats. Vector-Borne and Zoonotic Diseases 13(7): 498-504. doi: 10.1089/vbz.2012.1113

Thomas ME (1974) Bats as a food source for Boa constrictor. Journal of Herpetology 8(2): 188-188. doi: 10.2307/1562818

Toulkeridis T, Addison A, Constantin S, Winkler E, Toomey III R, Osburn R, Simón Baile D (2015) Espeleología en Tena, Napo. Un breve inventario geológico y cartográfico. In: Toulkeridis T, Constantin S, Addison A (Eds) $3^{\text {er }}$ Simposio Internacional de Espeleología en el Ecuador - Tena. Boletín Científico. Imprenta de la Universidad de las Fuerzas Armadas - ESPE, Sangolquí, 26-67.

Uetz P, Hallermann J (2016) Epicrates cenchria (Linnaeus, 1758). http://reptile-database.reptarium.cz/species?genus=Epicrates\&species=cenchria

Vargas J, Landaeta C, Simonetti JA (2002) Bats as Prey of Barn Owls (Tyto alba) in a Tropical Savanna in Bolivia. Journal of Raptor Research 36(2): 146-148.

Whitaker JO, Sparks DW, Brack V (2006) Use of artificial roost structures by bats at the Indianapolis International Airport. Environ Manage 38(1): 28-36. doi: 10.1007/s00267005-0117-2

Wilson D, Reeder D (Eds) (2005) Mammal Species of the World. A Taxonomic and Geographic Reference (3 eds). Johns Hopkins University Press, Baltimore, 2142 pp.

Wimsatt WA (1969) Transient behavior, nocturnal activity patterns, and feeding efficiency of vampire bats (Desmodus rotundus) under natural conditions. Journal of Mammalogy 50(2): 233-244. doi: 10.2307/1378339

Zortea M, Bastos NA, Acioli TC (2015) The bat fauna of the Kararao and Kararao Novo caves in the area under the influence of the Belo Monte hydroelectric dam, in Para, Brazil. Brazilian Journal of Biology 75(3 Suppl 1): 168-173. doi: 10.1590/1519-6984.00414bm 